\title{
Implementasi Pembelajaran Fiqih Materi Sholat Dengan Media Audio Visual Di Madrasah Ibtidaiyah
}

\author{
Sodikin \\ MI Salafiyah Syafi'iyah \\ sodikin8971@gmail.com \\ Khotim Ashom \\ MA ASRI Jember \\ Kashom78@gmail.com
}

DOI: 10.35719/educare.v2i1.52

\begin{abstract}
This research was conducted to form students to be more disciplined in maintaining time, especially in prayer, as well as to strengthen aqidah and increase the worship of students of Madrasah Ibtidaiyah Salafiyah Syafi'iyah. The focus of this research is: 1) How to plan the prayer chapter of fiqh learning through audio-visual media for students of Class IV Madrasah Ibtidaiyah Salafiyah Syafi'iyah Ajung, 2) How to implement the prayer chapter of figh learning through audio-visual methods for students of Class IV Madrasah Ibtidaiyah Salafiyah Syafi 'iyah Ajung, 3) How is the evaluation of figh learning in the prayer chapter for fourth grade students of Madrasah Ibtidaiyah Salafiyah Syafi'iyah Ajung. This research uses qualitative research with descriptive qualitative research. Determination of research subjects in this study was carried out purposively. Data collection techniques used observation, interviews, and documentation. Analysis of the data, the researcher used the data analysis model of the Miles, Huberman, and Saldana models including: Data Condensation (Condensation), Data Presentation (Display), Conclusions Drawing. The validity of the data in this study used source triangulation and technical triangulation. The results showed that: 1) The use of audiovisual media was very relevant in learning fiqh in the prayer chapter 2) Active, innovative, creative, effective and fun learning made students enthusiastic and enthusiastic in learning and not boring. 3) the completeness of learning facilities and infrastructure is very influential in the evaluation stage including summative evaluation and formative evaluation, input evaluation, process evaluation and output evaluation.
\end{abstract}

Keywords: Implementation; Fiqh learning; Audio visual 


\begin{abstract}
Abstrak
Penelitian ini dilakukan untuk membentuk peserta didik lebih disiplin dalam menjaga waktu khususnya dalam shalat, serta memantapkan aqidah dan meningkatkan ibadah peserta didik Madrasah Ibtidaiyah Salafiyah Syafi'iyah. Fokus penelitianini adalah: 1) Bagaimana Perencanaan Pembelajaran fiqih bab sholat melalui media audio visual bagi peserta didik Kelas IV Madrasah Ibtidaiyah Salafiyah Syafi'iyah Ajung, 2) Bagaimana Pelaksanaan pembelajaran fiqih bab sholat melalui metode audio visual bagi peserta didik Kelas IV Madrasah Ibtidaiyah Salafiyah Syafi'iyah Ajung, 3) Bagaimana evaluasi pembelajaran fiqih bab sholat bagi peserta didik kelas IV Madrasah Ibtidaiyah Salafiyah Syafi'iyah Ajung. Penelitian ini menggunakan penelitian kualitatif dengan jenis penelitian kualitatif deskriptif. Penentuan subyek penelitian dalam penelitian ini dilakukan secara purposive.Teknik pengumpulan data menggunakan observasi, wawancara, dan dokumentasi. Analisis data, peneliti menggunakan model analisis data model Miles, Huberman, dan Saldana meliputi: Kondensasi Data (Condensation), Penyajian Data (Display), Penarikan Kesimpulan (Conclusions Drawing). Keabsahan data dalam penelitian ini menggunakan triangulasi sumber dan triangulasi teknik.Hasil penelitian menunjukkan, bahwa: 1) Penggunaan media audiovisual sangat relevan dalam pembelajaran fiqih bab sholat 2) Pembelajaran aktif, inovatif, kreatif, efektif, dan menyenangkan membuat peserta didik semangat dan antusias dalam belajar serta tidak membosankan. 3) kelengkapan sarana dan prasarana pembelajaran sangat berpengaruh pada tahap evaluasi meliputi evaluasi Sumatif dan evaluasi Formatif evaluasi input, evaluasi proses dan evaluasi output.
\end{abstract}

\title{
Kata Kunci: Implementasi; Pembelajaran Fiqih; Audio Visual
}

\section{PENDAHULUAN}

Allah SWT menciptakan manusia sebagai makhluknya yang terbaik diantara makhluk-makhluk yang lain. Baik secara fisik maupun secara mental, karena manusia dilengkapi dengan akal, pikiran, hati, dan hawa nafsu. Namun berbagai kelengkapan yang diberikan oleh Allah dapat berkembang apabila diarahkan melalui pendidikan. Manusia merupakan mahluk Allah SWT yang selalu membutuhkan pendidikan dalam pertumbuhan dan perkembangannya. Sebagaimana Firman Allah dalam surat An-Nahl ayat 125: 


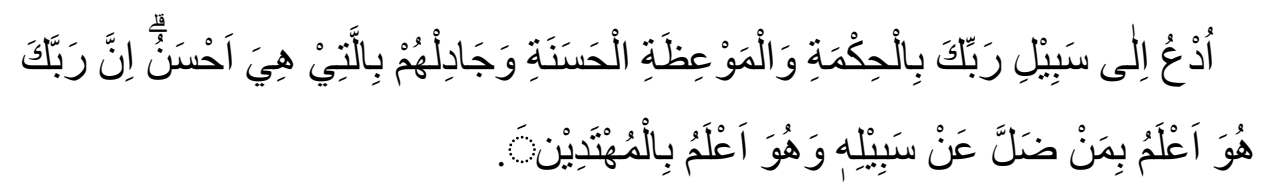

Artinya:"Serulah (manusia) kepada jalan Tuhan-mu dengan hikmah dan pelajaran yang baik, sesungguhnya Tuhan Mu Dialah yang lebih mengetahui siapa yang sesat dari jalannya, dan Dialah yang lebih mengetahui siapa yang mendapat petunjuk”. (Q.S. An-Nahl:125). ${ }^{1}$

Ayat ini menjelaskan tentang ajakan menyampaikan pembelajaran menuju jalan Allah dan mentaati-Nya dengan cara hikmah, mau'idhatulhasanah dan mengkajinya dengan argumen yang baik. Tiga model dakwah ini menarik untuk dibahas. Menyampaikan kebaikan bukan hanya mengajak fisik tubuh, tapi ruh dan akal pikiran. Hikmah adalah nikmat besar yang Allah berikan kepada orang yang khusus. Menyampaikan dengan hikmah mengedepankan substansi, metodologi, etika Hikmah juga bermakna sesuatu yang baik, disampaikan pada waktu dan tempat yang tepat.Adapun mau'idhah hasanah, berarti menasehati dengan ajaran Al-Quran yang merupakan intisari ilmu dan kebenaran, bukan dengan kekerasan.Ketiga, jadal. Secara harfiah, jadal bermakna debat diskusi yaitu memahami bahwa berdebat dengan cara yang baik dengan menunjukkan hujjat (argumentasi) yang kuat. Argumentasi itu kemudian disampaikan dengan cara yang lembut.

Pendidikan merupakan antisipatoris, karena segala yang dilaksanakan pada pendidikan sekarang diterapkan dalam kehidupan pada masa yang akan datang. Pendidikan merupakan sebuah proses sekaligus sistem yang bermuara dan berujung pada pencapaian kualitas kehidupan manusia. Sehingga pendidikan dikatakan sebagai wahana mengasuh, membimbing, dan mendidik putra-putri generasi penerus estafet perjuangan bangsa untuk melaksanakan amar ma'ruf nahi mungkar, agar bisa menjadi warga negara yang baik, berkualitas, memiliki keseimbangan dalam hidup antara duniawi

\footnotetext{
${ }^{1}$ Kementrian Agama RI Al-Qur'an dan Terjemah, (NEW CORDOVA)
} 
dan ukhrowi.

Pendidikan adalah usaha sadar, terencana mewujudkan suasana belajar dan proses pembelajaran peserta didik secara aktif, mengembangkan potensi dirinya, memiliki kekuatan spiritual keagamaan, pengendalian diri, kepribadian, kecerdasan, akhlak mulia serta keterampilan yang diperlukan dirinya, bangsa, dan negara. ${ }^{2}$ Tujuan pendidikan mengembangkan potensi peserta didik agar menjadi manusia yang beriman dan bertakwa kepada Tuhan Yang Maha Esa, berakhlak mulia, sehat, berilmu, cakap, kreatif, mandiri, menjadi warga negara yang demokratis serta bertanggug jawab. ${ }^{3}$ Merupakan kebutuhan mutlak mencerdaskan anak bangsa, membangun moral, kepribadian, mental dan akhlak mulia sebagai tiang penyangga bagi agama, bangsa dan negara. Untuk itu idealnya pendidikan tidak hanya sekedar sebagai transfer ilmu pengetahuan dan ketrampilan, lebih dari itu adalah transfer perilaku yang positif dan lebih baik untuk mengembangakan potensi dirinya. Sebagaimana telah diungkapkan oleh Mulyasa tentang pengertian pendidikan, mengatakan bahwa: Pendidikan adalah proses pembelajaran yang tujuannya untuk mengembangkan potensi diri peserta didik secara aktif serta memiliki kekuatan spiritual keagamaan, pengendalian diri, kecerdasan, akhlak mulia, serta keterampilan yang diperlukan dirinya dan masyarakat. ${ }^{4}$

Secara pedagogis, pendidikan agama harus dimulai dari sejak kecil. Betapa pentingnya pendidikan agama itu bagi setiap warga Indonesia, terbukti dari adanya peraturan pemerintah yang mengharuskan pendidikan agama itu diberikan kepada setiap anak sejak anak itu bersekolah di taman kanak-kanak sampai dengan perguruan tinggi. Pendidikan agama mencangkup 3 aspek yaitu: aspek kognitif, afektif, dan psikomotor. Ini

\footnotetext{
${ }^{2}$ Husaini Usman, Manajemen Teori, Praktek Dan Riset Pendidikan, (Jakarta: PT Bumi Aksara, 2006), 7.

${ }^{3}$ Dedi Supriyadi, Membangun Bangsa Melalui Pendidikan, (Bandung: PT Remaja Rosdakarya, 2005), 121-122.

${ }^{4}$ Mulyasa, Kurikulum Tingkat Satuan Pendidikan, (Bandung: Remaja Rosdakarya, 2007), 4.
} 
berarti bahwa pendidikan agama bukan hanya sekedar memberi pengetahuan tentang keagamaan, melainkan justru yang lebih utama adalah membiasakan anak taat dan patuh menjalankan ibadah dan berbuat serta bertingkah laku di dalam kehidupannya sesuai dengan norma-norma yang telah ditetapkan dalam agama masing-masing. Dengan pemberian materi agama Islam diharapkan mampu mengembangkan kehidupan manusia antara kepentingan duniawi dan ukhrowi.

Hazanah pendidikan Islam adalah pendidikan yang mampu membentuk manusia yang unggul secara Intelektual, kaya dalam amal serta anggun dalam moral dan kebijakan seluruh kekuatan dan jalur pendidikan Islam di Indonesia haruslah diarahkan secara strategis untuk lebih memperkaya corak budaya bangsa dengan nilai-nilai yang anggun. Misalnya dalam pendidikan Madrasah Ibtidaiyah yang bersifat formal, Religius yang penuh kompetetif di era modern saat ini.

Pendidikan Madrasah ibtidaiyah yang tumbuh dan lahir dari kultur masyarakat Indonesia yang bersifat Indigenous. Lembaga inilah yang dilirik kembali sebagai model dasar pengembangan konsep pendidikan di Indonesia. Dengan demikian, pendidikan Madrasah ibtidaiyah mulai diperhatikan dari multi perspektif sehingga tidak selalu dinilai negatif.Memang masih terdapat kekurangandari sistem pendidikan Madrasah sehingga harus dikritik, tetapi ada juga kelebihan-kelebihan tertentu yang perlu dicontoh bahkan harus dikembangkan.

Perpaduan antara sekolah formal dan sekolah diniyah, itulah yang dimaksud dengan kata kolaboratif dalam jenis Pendidikan Islam berbasis Sekolah. merupakan hal yang penting karena pengajaran agama akan menghasilkan pengetahuan agama sekaligus menjadikan pengalaman, sehingga akan terwujudkan diri seseorang ilmu, amal dan taqwa, atau kata lain arah pendidikan agama adalah untuk membina peserta didik agar menjadi warga negara yang baik dan sekaligus menjadi umat yang taat beragama. Pendidikan Islam adalah untuk membina manusia beragama yang 
mampu melaksanakan ajaran agama Islam dengan baik dan sempurna, sehingga tercermin sikap dan tindakan dalam seluruh kehidupan, dalam rangka mencapai kebahagiaan hidup didunia dan akhirat. Diwajibkan bagi kita untuk belajar, terutama untuk belajar agama. Proses dan tujuan pembelajaran yang baik dan sesuai dengan rencana adalah hal yang sangat diharapkan. Untuk itu perlulah didukung sarana dan prasarana yang memadai baik yang bersifat material maupun immaterial. Hal ini tak terkecuali dalam pembelajaran materi fiqih yang merupakan bagian dari Pendidikan Agama Islam (PAI) di Madrasah Ibtidaiyah yang membutuhkan proses pembelajaran yanginovatifdan mumpuni. Hal ini tidak berlebihan karena pada dasarnya materi fiqih berhubungan erat dengan syari'at dalam agama Islam baik yang berkaitan dengan ibadah maupun muamalah. ${ }^{5}$

Materi fiqih yang berhubungan dengan syari'at dan praktek dari syari'at itu sendiri (ibadah dan muamalah) secara otomatis mengindikasikan adanya materi-materi yang sangat berkaitan dengan perbuatan manusia. Oleh sebab itu, dalam dunia pendidikan terus mengalami perkembangan yang cukup signifikan, Madrasah Ibtidaiyah memiliki semangat untuk selalu memberikan PAIKEMI (Pembelajaran, Aktif, Inovatif, Kreatif, Efektif, Menyenangkan, dan Islami) kepada peserta didik sehingga mereka terbawa dalam suasana belajar nyaman serta tidak membosankan.

Madrasah Idtidaiyah Salafiyah Syafi'iyah Pancakarya Ajung memasukkan kegiatan tahfidzul Qur'an serta Ektrakurikuler lainnya seperti: Hadrah, Drumband, Pramuka, Pencak Silat, serta pendidikan dasar Komputer, namun pembelajaran agama terutama pembelajaran fiqih materi sholat lebih diutamakan, antaralain dengan menggunakan cara belajar yang mudah diterima melalui metode yang menyenangkan, yaitu pembelajaran dengan media audio visual agar peserta didik mendalami serta melihat langsung tata cara sholat yang benar dengan memperhatikan langsung video

\footnotetext{
${ }^{5}$ A. Syafi'i Karim, Fiqh Ushul Fiqh, (Bandung: Pustaka Setia, 1997), 78.
} 
tentang tuntunan sholat yang telah disesuaikan antara gerakan dan bacaanbacaannya dengan benar.

Audio visual merupakan salah satu media pembelajaran yang digunakan di Madrasah Ibtidaiyah Ajung. Hal inilah yang menjadi daya tarik bagi penulis untuk melakukan penelitian mengenai Implementasi pembelajaran fiqih bab sholat bagi peserta didik kelas IV Madrasah Ibtidaiyah. Pembelajaran fiqih bab shalat lebih diutamakan sejak pendidikan Madrasah Ibtidaiyah yang didampingi serta difasilitasi oleh guru agar semua peserta didik dapat mempraktekan dan melaksanakan dalam kesehariannya dengan benar, karena Ibadah Sholat merupakan cermin dan tolak ukur dari semua amal perbuatan manusia maka, Sholat harus di laksanakan dengan tepat dan benar sebagaimana sabda Nabi Muhammad SAW, diriwayatkan Oleh Imam Bukhari, Artinya:"Dari Malik bin Huwairits ra berkata: Rasulullah SAW berkakata Sholatlah kalian sebagaimana kalian melihat aku Sholat". 6

Secara substansial pemahaman pemahaman fiqih bab sholat memiliki kontribusi dalam memberikan motivasi kepada semua Peserta didik Madrasah Ibtidaiyah Salafiyah Syafi'iyah Ajung untuk dapat mempraktekan dan menerapkan syari'at Islam dalam kehidupan sehari-hari sebagai perwujudan keserasian, keseimbangan hubungan manusia dengan Allah SWT, hubungan manusia dengan manusia itu sendiri, serta hubungan dengan makhluk lainnya ataupun lingkungannya. Dengan pembelajaran ini, tentunya guru berharap adanya pemahaman fiqih khusunya tentang Sholat kepada para peserta didiknya untuk menerapkan dalam kehidupan seharihari, baik ketika berada di Madrasah maupun ketika berada di tengah-tengah lingkungan masyarakat.

Pemahaman fiqih setiap peserta didik berbeda-beda, tidak diketahui apakah mereka diam karena mereka sudah paham, atau ada sebab-sebab

\footnotetext{
${ }^{6}$ Bulughul Marom, (Surabaya: ‘Arofah jaya), 75.
} 
lain. Kurangnya hubungan timbal balik antara guru terhadap peserta didiknya, akan bisa menimbulkan efek negatif ketika peserta didik dapat memanifestasikan hasil belajarnya tersebut kedalam kehidupan sehari-hari, mengingat pentingnya pemahaman serta penerapan terhadap ajaran-ajaran yang ada dalam syari'at Islam dan apabila pemahaman, penerapan terhadap peserta didik materi yang disampaikan kurang pas, maka dalam merealisasikan hasil belajar tersebut di tengah-tengah masyarakat akan berakibat fatal/kurang baik. Maka untuk mengetahui dan mengukur sejauh mana pemahaman peserta didik terhadap implementasi pembelajaran fiqih bab shalat bagi peserta didik kelas IV di Madrasah Ibtidaiyah tentunya masih diperlukan perhatian serta penelitian yang lebih dalam.

Media adalah semua bentuk perantara yang dipakai orang penyebar ide, sehingga ide atau gagasan itu sampai pada penerima. ${ }^{7}$ Gerlach \& Ely, sebagaimana dikutip oleh Arsyad Azhar mengatakan bahwa media adalah manusia, materi, atau kejadian yang membangun kondisi membuat peserta didik mampu memperoleh pengetahuan, keterampilan, atau, sikap. Dalam pengertian ini guru, buku teks, dan lingkungan sekolah merupakan media. ${ }^{8}$

Fleming, sebagaimana dikutip oleh Arsyad Azhar mengatakan bahwa media adalah penyebab atau alat yang turut campur tangan dalam dua pihak dan mendamaikannya. Dengan istilah mediator media menunjukkan fungsi atau perannya, yaitu mengatur hubungan yang efektif antara dua pihak utama dalam proses belajar peserta didik dan isi pelajaran. ${ }^{9}$ Heinich dan kawan-kawan, sebagaimana dikutip oleh Arsyad Azhar mengemukakan istilah medium sebagai perantara yang mengantar informasi antara sumber dan penerima. Jadi, televisi, film, foto, radio, rekaman audio, gambar yang diproyeksikan, bahan-bahan cetakan dan sejenisnya adalah media komunikasi.

\footnotetext{
${ }^{7}$ Rohani Ahmad, Media Intruksional Edukatif, (Jakarta: PT.Rineka Cipta,1997), 56.

${ }^{8}$ Azhar Arshad, Media Pembelajaran, (Jakarta: PT. Raja Grafindo Persada, 2007), 3.

${ }^{9}$ Ibid, 3 .
} 
Hamidjojo dalam Latuheru, sebagaimana dikutip oleh Arsyad Azhar memberi batasan sebagai semua bentuk perantara yang digunakan oleh manusia untuk menyampaikan atau menyebar ide, gagasan, atau pendapat sehingga ide, gagasan atau pendapat yang dikemukakan itu sampai kepada penerima yang dituju. ${ }^{10}$ Gagne dan Briggs, sebagaimana dikutip oleh Arsyad Azhar secara implisit mengatakan bahwa media pembelajaran meliputi alat yang secara fisik digunakan untuk menyampaikan isi, materi pengajaran, yang terdiri dari antara lain: buku, tape recorder, kaset, video, camera, video recorder, film, slide (gambar bingkai), foto, gambar grafik, televisi, dan komputer. Dengan kata lain media adalah komponen sumber belajar atau wahana fisik yang mengandung materi instruksional di lingkungan peserta didik untuk belajar. ${ }^{11}$

Dari definisi para ahli media tersebut dapat diambil kesimpulan bahwa media adalah alat bantu apa saja yang dapat dijadikan sebagai penyalur pesan guru mencapai tujuan pengajaran. Dengan media yang tepat tujuan pengajaran bisa terlaksana dengan baik serta pesan pembelajaran yang disampaikan dengan menggunakan metode yang menyenangkan bisa dipahami oleh peserta didik dengan rasa senang. Audio adalah suara yang dihantarkan oleh gelombang udara yang dapat didengar oleh telinga manusia. Karena audio berhubungan dengan pendengaran.Visual adalah gambar yang menunjukkan sesuatu yang dapat dilihat. Jadi audio visual adalah media yang mempertunjukkan gambar dan mendengarkan suara.

Menurut Djamarah sebagai alat bantu dalam pendidikan dan pengajaran, alat material (audio visual) mempunyai sifat sebagai berikut: (1) Kemampuan untuk meningkatkan persepsi, (2) Kemampuan untuk meningkatkan pengertian, (3) Kemampuan untuk meningkatkan transfer (pengalihan) belajar, (4) Kemampuan untuk memberikan penguatan (reinforcement) atau pengetahuan hasil yang dicapai, (5) Kemampuan untuk

\footnotetext{
${ }^{10}$ Azhar Arshad, Media, 3

${ }^{11}$ Ibid, 3.
} 
meningkatkan retensi (ingatan).

Media audio visual digunakan dalam upaya peningkatan atau mempertinggi mutu proses kegiatan belajar mengajar. Agar dapat mengoptimalkan peranan media pembelajaran yang digunakan untuk mencapai tujuan pembelajaran, maka harus diperhatikan prinsip-prinsip penggunaannya antara lain: ${ }^{12}$ a) Penggunaan media pembelajaran hendaknya dipandang sebagai bagian integral dari suatu sistem pengajaran. b) Sebagai sumber belajar yang digunakan dalam pemecahan masalah yang dihadapi dalam proses belajar mengajar, c) Guru harus benar-benar menguasai teknik dari media pembelajaran yang digunakan. d) Guru harus memperhitungkan untung ruginya penggunaan media pembelajaran, e) Penggunaan media pengajaran harus diorganisir secara sistematik bukan sembarangan menggunakannya, f) Jika suatu pokok bahasan memerlukan lebih dari satu macam media maka guru dapat memanfaatkan multimedia yang memperlancar proses belajar mengajar.

Manfaat penggunaan media audio visual di dalam proses belajar mengajar cukup praktis dan bermanfaat karena: a) Media audio visual dapat memperjelas penyajian pesan informasi sehingga dapat memperlancar dan meningkatkan proses belajar dan hasil belajar. b) Media audio visual meningkatkan dan mengarahkan perhatian anak sehingga dapat menimbulkan motivasi belajar, interaksi yang lebih langsung antara peserta didik dan lingkungannya dan kemungkinan peserta didik untuk belajar sendiri-sendiri sesuai dengan kemampuan dan minatnya. c) Media audio visual dapat mengatasi keterbatasan indera, ruang, waktu serta obyeknya. d) Media audio visual dapat memberikan kesamaan pengalaman kepada peserta didik tentang peristiwa di lingkungan mereka serta memungkinkan terjadinya interaksi langsung dengan guru, masayarakat serta

\footnotetext{
${ }^{12}$ Ibid, 3.
} 
lingkungannya. ${ }^{13}$

Dalam proses pembelajaran audio visual fungsi utamanya adalah sebagai alat bantu mengajar yang turut mempengaruhi iklim, kondisi dan lingkungan belajar yang ditata dan diciptakan oeh guru. Menurut Hamalik, sebagaimana dikutip oleh Azhar bahwa pemakaian media audio visual dalam proses belajar dapat membangkitkan keinginan dan minat yang baru, membangkitkan motivasi, rangsangan kegiatan belajar dan membawa pengaruh psikologis terhadap peserta didik. ${ }^{14}$ Nana Sudjana, sebagaimana dikutip oleh Azhar merumuskan fungsi media audio visual menjadi enam kategori yaitu: a) Penggunaan media dalam proses belajar mengajar berfungsi sebagai alat Bantu untuk mewujudkan situasi belajar mengajar yang efektif, b) Penggunaan media pengajaran merupakan bagian yang integral dari keseluruhan situasi mengajar, c) Penggunaan media dalam pengajaran bukan semata-semata alat hiburan, d) Penggunaan Media dalam kegiatan pengajaran lebih diutamakan untuk mempercepat proses belajar mengajar dan membantu peserta didik dalam menangkap pengertian yang diberikan guru, e). Penggunaan media dalam pengajaran diutamakan untuk mempertinggimutu belajar mengajar. ${ }^{15}$ Dengan berbagai pertimbangan maka penulis mengambil judul implementasi Implementasi pembelajaran fiqih Materi sholat dengan media audio visual bagi peserta didik Kelas IV Madrasah Ibtidaiyah Salafiyah Syafi'iyah Ajung.

\section{METODE PENELITIAN}

Pendekatan yang di gunakan dalam penelitian ini adalah pendekatan kualitatif. Penelitian kualitatif adalah suatu prosuder penelitian yang dihasilkan data diskriptif yang berupa kata-kata tertulis atau lisan dari orang-orang atau perilaku yang di amati. ${ }^{16}$ Jenis penelitian yang di gunakan

\footnotetext{
${ }^{13}$ Azhar Arsyad, Media, 26

${ }^{14}$ Ibid 26

${ }^{15}$ Azhar Arsyad, Media, 16.

${ }^{16}$ Lexi J. Moleong, Metode Penelitian Kualitatif, (Bandung: PT Remaja Rosdakarya,2010), 4.
} 
adalah kualitatif deskriptif. Penelitian deskriptif adalah penelitian yang di gunakan untuk menggambarkan (to describe), menjelaskan dan menjawab persoalan-persoalan tentang fenomena dan peristiwa yang terjadi saat ini, baik tentang fenomena sebagaimana adanya maupun analisis hubungan antara berbagai variabel dalam suatu fenomena. ${ }^{17}$ Lokasi penelitian menunjukkan dimana penelitian akan di lakukan. Peneliti mengambil lokasi penelitian di Madrasah Ibtidaiyah Salafiyah Syafi'iayah Ajung yang berada di Jln.Cendrawasih No. 39 desa Pancakarya Kecamatan Ajung Kabupaten Jember. Subyek penelitian yaitu orang yang berkaitan dengan penelitian yang menjadi pelaku dari suatu kegiatan yang diharapkan dapat memberikan informasi yang terkait dengan penelitian yang dilakukan. Subyek penelitian merupakan sumber data untuk mendapatkan atau memperoleh informasi yang dibutuhkan dalam penelitian. ${ }^{18}$ Penentuan subyek penelitian dalam penelitian ini dilakukan secara purposive, yaitu pengambilan sumber data dipilih dengan pertimbangan tertentu. ${ }^{19}$ Pertimbangan tertentu misalnya subyek penelitian yang dipilih dianggap orang yang paling tahu dan mengerti serta dapat memberikan informasi yang dibutuhkan dalam penelitian, sehingga akan memudahkan peneliti dalam melakukan penelitian. Sedangkan sumber data menurut sifatnya (ditinjau dari tujuan penyelidikan) dapat digolongkan menjadi dua golongan. ${ }^{20}$ Sumber primer (sumber-sumber yang memberikan data langsung dari tangan pertama) dan sumber sekunder (sumber yang mengutip dari sumber lain). Yang sifatnya relevan dengan sumber penenlitian

\footnotetext{
${ }^{17}$ Zainal Arifin, Penelitian PendidikanMetode Dan Paradigma Baru, (Bandung :Remaja Rosda Karya , 2012), 41.

${ }^{18}$ Suharsimi Arikunto, Prosedur Penelitian Kuantitatif, dan $R \& D$ (Bandung: Alfabeta, 2014), 216.

${ }^{19}$ Sugiyono, Metode Penelitian Pendidikan (Pendekatan Kualitatif, Kuantitatif, R\&D) (Bandung: Alfabeta, 2013), 300.

${ }^{20}$ Winarno Surakhmad, Pengantar Penelitian Ilmiah Dasar, Metode dan Teknik (Bandung: Tersito, 1980), 134.
} 


\section{HASIL DAN PEMBAHASAN TEMUAN}

Dari data-data yang telah diperoleh dilapangan yang sudah dilakukan oleh penulis melalui observasi dan wawancara serta dokumentasi, kemudian disajikan dalam bentuk penyajian data, selanjutnya dianalisis kembali sesuai dengan fokus masalah yang ada dalam penelitian sebagai berikut:

Perencanaan Pembelajaran Fiqih Materi Sholat Melalui Media Audio Visual Bagi Peserta Didik Kelas IV Madrasah Ibtidaiyah Salafiyah Syafi'iyah Ajung

Beradasarkan penelitian yang telah di lakukan maka dapat di paparkan pembahasan temuan dalam penelitian ini adalah pembuatan perencanaan pembelajaran fiqih melalui media audio visual bagi peserta didik kelas IV Madrasah Ibtidaiyah Salafiyah Syafi'iyah Pancakarya Ajung Jember di laksanakan agar dapat mempermudah pelaksanaan pembelajaran.

Perencanaan merupakan hal yang terpenting sebelum melakukan sesuatu kegiatan, jika kita melakukan sesuatu kegiatan dengan merencanakannya terlebih dahulu, maka kegiatan tersebut akan lebih terarah. Keberhasilan dari suatu kegiatan pembelajaran sangat ditentukan oleh perencanaannya yang dilakukan oleh lembaga pendidikan. Apabila perencanaan suatu kegiatan dirancang dengan baik, maka kegiatan tersebut mudah dilaksanakan, terarah serta terkendali sesuai dengan tujuan dan visimisi pembelajaran yang akan dilaksanakan. ${ }^{21}$

Selaras dengan teori perencanaan salah satu aspek dari tujuan pendidikan adalah memelihara, mempertahankan, dan mngembangkan bagian dari tujuan yang menjadi dasar integrasi dari perencanaan masyarakat dan perencanaan pembelajaran. Perencanaan dapat menolong pencapaian suatu sasaran secara lebih ekonomis, tepat waktu dan memberi peluang untuk lebih mudah di kontrol dan di monitor dalam

\footnotetext{
${ }^{21}$ Abdul Karim dan Luluk Handayani. "Pengelolaan Open and Distance Learning Di TK Muslimat NU 41 Wuluhan Jember". GENIUS: Indonesian Journal of Early Childhood $\begin{array}{lllll}\text { Education } 1, & \text { no. } 1 \text { (June 2020): } 27 . & \text { https://genius.iain- }\end{array}$ jember.ac.id/index.php/gns/article/view/5.
} 
pelaksanaannya. $^{22}$

Perencanaan pada pembelajaran fiqih materi shalat melalui media audio visual dibuat secara terperinci dan matang, begitu juga perencanaan pada setiap pembelajran Yang di laksanakan, caranya adalah sesuai dengan pembahasan di atas yaitu: (1) Guru menyusun jadwal materi selama satu tahun, (2) Menentukan target pembelajaran fiqih, (3) Guru menentukan media-media pembelajaran, (4) Menentukan metode praktikum. Dalam penyusunan program tahunan para guru PAI Madrasah Ibtidaiyah Salafiyah Syafi'iyah Pancakarya Ajung bersama waka kurikulum menentukan dan menyusun jadwal materi selama satu tahun serta menentukan jam tugas mengajar bagi masing-masing guru dengan menyusun Program Semester, Rencana Pelaksanaan Pemberlajaran (RPP), Materi pelajaran fiqih, aqidah akhlaq, sejarah kebudayaan Islam, dan muatan lokal Aswaja.

Pelaksanaan Pembelajaran Fiqih Materi Sholat Melalui Media Audio Visual Bagi Peserta Didik Kelas IV MI Salafiyah Syafi'iyah Ajung

Pelaksanaan merupakan aplikasi dari perencanaan yang telah di buat terlebih dahulu. Setiap proses belajar guru mempunyai berbagai model dan metode belajar sehingga peserta didik dapat belajar dengan efektif dan efisien. Salah satu yang dapat menentukan keberhasilan dalam belajar erat kaitannya dengan model belajar yang di pakai guru. Pemilihan dan penggunaan model belajar haruslah yang membuat peserta didik belajar dengan aktif, dengan kata lain guru harus mempertimbangkan pemilihan model belajar yang di gunakan, apakah model tersebut dapat mendorong peserta didik lebih aktif berfikir dan dapat memecahkan masalah.

Pada pembelajaran fiqih materi sholat melalui media audio visual bagi peserta didik kelas IV Madrasah Ibtidaiyah Salafiyah Syafi'iyah Pancakarya Ajung sebelum pelaksanaan pembelajaran dimulai, guru melakukan persiapan terhadap sarana dan prasarana yang digunakan didalam kelas

\footnotetext{
${ }^{22}$ Harjanto, Perencanaan Pengajaran(Jakarta:Rineka Cipta, 1997), 22.
} 
antara lain: laptop, proyektor, audio (pengeras suara) kemudian guru 1) Melakukan pengaturan peserta didik di dalam kelas, dengan membuat kelompok terpisah antara peserta didik dan siswi. 2) Menjelaskan materi fiqih melalui media audio visual, 3) Memberikan waktu tanya jawab, 4) Melaksanakan praktikum dan evaluasi.

Berdasarkan hasil observasi, pemilihan dan penggunaan model pembelajaran fiqih materi sholat melalui media audio visual membantu dan mempermudah untuk peserta didik kelas IV dalam belajar dan memahami materi sholat, keberagaman gaya belajar yang dimiliki peserta didik kelas IV A dengan disiplin serta mencemati gambar video sholat yang ditayangkan melalui proyektor dan kelas IV B, yang kritis serta banyak bertanya menjadi tantangan bagi guru mata pelajaran fiqih dalam melaksanakan pembelajaran. Agar materi yang disampaikan mengena serta mudah diterima peserta didik, maka guru mata pelajaran fiqih (Ahmad Arif) menyususn RPP yang sesuai dengan materi pelajaran fiqih kelas IV yang disampaikan serta menggunakan model belajar dengan media audio visual dan praktikum seperti yang di jelaskan Colin dan Malkon dalam bukunya di sebutkan bahwa, ada sebuah penelitian yang menyatakan telah mengidentifikasi gaya belajar dan komunikasi yang optimal yaitu visual, auditori, dan kinestetik. $^{23}$

Pada kegiatan awal pembelajaran fiqih materi sholat melalui media audio visual bagi peserta didik kelas IV ada beberapa yang juga dilakukan oleh guru mapel fiqih antara lain adalah a) memberikan sugesti dan pengarahan yang baik bagi peserta didik, b) memberikan pernyataan yang bermanfaat kepada peserta didik, c) memberikan gambaran dan tujuan yang jelas dan bermakna, d) Menciptakan lingkungan fisik dan emosional sosial yang positif, e) Menanamkan rasa taat dan patuh.

Pada kegiatan awal pembelajaran guru telah membuat perencanaan

\footnotetext{
${ }^{23}$ Meier, Panduan Kreatif Dan Efektif Merancang Program Pendidikan Dan Pelatihan, (Bandung: PT Abadi, 2007), 234.
} 
pelaksanaan pembelajaran dengan mempersiapkan media-media yang digunakan, guna menunjang kelancaran kegiatan belajar mengajar yang efektif dan efisien. Sebelum pembelajaran di mulai guru memberikan sugesti positif dengan mengajak peserta didik bernyanyi dengan memberikan sedikit mainan dan kemudian guru memberikan sedikit stimulus (rasa ingin tahu) dan pengenalan kepada peserta didik tentang apa yang akan dipelajari dengan bahasa yang menarik dan media yang menarik pula sehingga peserta didik antusias dan menumbuhkan rasa ingin tahu terhadap materi tersebut.

\section{Evaluasi Pembelajaran Fiqih Bab Shalat Melalui Media Audio Visual} Bagi Peserta Didik Kelas IV Madrasah Ibtidaiyah Salafiyah Syafi'iyah

\section{Ajung}

Sebagaimana telah di jelaskan bahwasanya evaluasi sangatlah penting dalam proses pembelajaran, gunanya adalah untuk mengukur keberhasilan dari pembelajaran itu sendiri. Evaluasi dalam pembelajaran fiqih bab sholat melalui media audio visual ada 2 macam cara penilaiannya.

Pada setiap pembelajaran tidak hanya evaluasi yang di gunakan tetapi juga ada penilaian non tes. Penilaian non tes biasanya digunakan untuk menilai tentang sikap kebiasaan kerja kejujuran dan lain-lain. ${ }^{24}$ Berdasarkan hasil penelitian dan observasi yang dilakukan pada kegiatan evaluasi pembelajaran fiqih melalui media audio visual bagi peserta didik kelas IV MI Salafiyah Syafi'iyah Pancakarya Ajung adalah menggunakan evaluasi formatif dan evaluasi sumatif. Yaitu penilaian yang di maksudkan untuk mengetahui kemampuan peserta didik selama pembelajaran berlangsung, yaitu: pada akhir pembahasan dengan memberikan beberapa pertanyaan langsung terhadap peserta didik serta melalui praktekum, 2. penilaian di akhir semester. Penilaian ini digunakan oleh guru untuk mengukur

\footnotetext{
${ }^{24}$ Tritanto Ibnu Badar, Desain Pengembangan Pembelajaran, (Bandung: Cinta Umbara, 2011), 226.
} 
pemahaman peserta didik terhadap materi yang telah mereka terima selama proses pembalajaran.

\section{SIMPULAN}

Berdasarkan penelitian yang telah dilakukan maka dapat di ambil kesimpulan dari setiap fokus masalah dapat disimpulkan sebagai berikut: (1) perencanaan pembelajaran fiqih bab shalat melalui media audio visual bagi peserta didik kelas IV Madrasah Ibtidaiyah meliputi beberapa perencanaan yaitu: a. guru menyusun jadwal materi selama satu tahun dan satu semester, b. menentukan target pembelajaran fiqih dengan menyusun RPP, c. guru menentukan media-media pembelajaran, d. menentukan metode praktikum dan lain sebagainya. (2) Pelaksanaan pembelajaran fiqih bab shalat melalui media audio visual bagi peserta didik kelas IV Madrasah Ibtidaiyah meliputi beberapa pelaksanaan, yaitu: a. melakukan pengaturan peserta didik di dalam kelas dalam beberapa kelompok, b. menjelaskan materi fiqih melalui proyektor, c. melaksanakan tanya jawab dan praktikum. (3) Evaluasi pembelajaran fiqih bab shalat melalui media audio visual bagi peserta didik kelas IV Madrasah Ibtidaiyah menggunakan beberapa evaluasi yaitu: a) evaluasi formatif melalui pertanyaan soal yang di lakukan di akhir pembelajaran, meliputi tes tulis, tes lisan, dan praktik. 2) evaluasi sumatif yang meliputi, tes yang di lakukan pada akhir semester.

\section{DAFTAR PUSTAKA}

Abdul Karim dan Luluk Handayani. "Pengelolaan Open and Distance Learning Di TK Muslimat NU 41 Wuluhan Jember". GENIUS: Indonesian Journal of Early Childhood Education 1, no. 1 (June 2, 2020). https://genius.iain-jember.ac.id/index.php/gns/article/view/5

Ahmad, Rohani. Media Intruksional Edukatif. Jakarta: PT.Rineka Cipta,1997. 
Arifin, Zainal. Penelitian Pendidikan Metode Dan Paradigma Baru. Bandung: Remaja Rosda Karya, 2012.

Arshad, Azhar. Media Pembelajaran. Jakarta: PT. Raja Grafindo Persada, 2007.

Asqalani (al), Ibnu Hajar. Bulughul Marom. Surabaya: Arofah Jaya.

Hamalik, Oemar. Kurikulum dan Pembelajaran. Jakarta: Bumi Aksara, 2009.

Harjanto. Perencanaan Pengajaran. Jakarta: Rineka Cipta, 1997.

Husaini Usman, Manajemen Teori, Praktek Dan Riset Pendidikan. Jakarta: PT Bumi Aksara, 2006.

Karim, A. Syafi'i.Fiqh Ushul Fiqh. Bandung: Pustaka Setia, 1997.

Kementrian Agama RI Al-Qur'an dan Terjemah. NEW CORDOVA.

Mas'ud, M. Khalid. Shatibi's Phylosophy of Islamic Law. Malaysia: Islamic BookTrust, 2001).

Meier, Panduan Kreatif Dan Efektif Merancang Program Pendidikan Dan Pelatihan. Bandung: PT Abadi, 2007.

Mohamad, H.Surya. Psikologi Pembelajaran dan Pengajaran. Bandung: Pustaka Bani Quraisy, 2004.

Mulyasa. Kurikulum Tingkat Satuan Pendidikan. Bandung: Remaja Rosdakarya, 2007.

Mulyasa. Kurikulum Berbasis Kompetensi Konsep, Karakteristik, Implementasi, danInovasi. Bandung: Remaja Rosdakarya, 2003.

Nadjib, Zuhdi. Kamus Lengkap Praktis Inggris-Indonesia IndonesiaInggris. Surabaya: Fajar Mulia,1993.

Nata,Abuddin. Perspektif Islam Tentang Strategi Pembelajaran. (Jakarta: Kencana Prenada Media Group, 2009).

Rofiq, Ahmad. Hukum Islam di Indonesia. Jakarta: Raja Grafindo Persada, 2002.

Supriyadi, Dedi. Membangun Bangsa Melalui Pendidikan. Bandung: PT Remaja Rosdakarya, 2005.

Tritanto, Ibnu Badar. Desain Pengembangan Pembelajaran. Bandung: Cinta Umbara, 2011.

Yunus, Mahmud. Kamus Arab-Indonesia. Jakarta: PT Mahmud Yunus Wadzuriyah, tt. 